
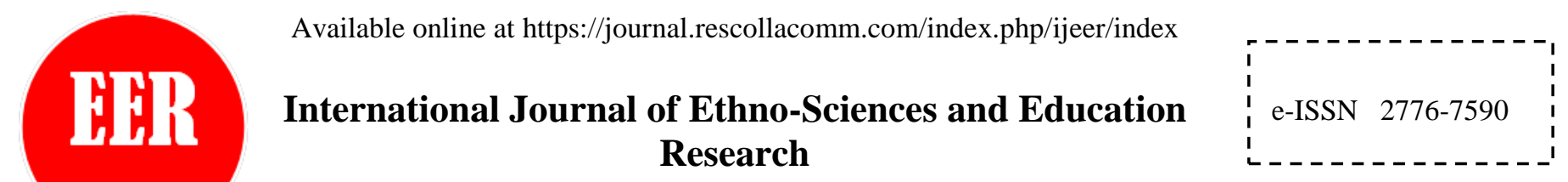

Vol. 1, No. 2, pp. 1-6, 2021

\title{
Arithmatics in Serat Centhini
}

\author{
Agung Prabowo ${ }^{1 *}$ \\ ${ }^{I}$ Department of Mathematics, Universitas Jenderal Soedirman, Purwokerto, Indonesia \\ *Corresponding author email: agung.prabowo@unsoed.ac.id
}

\begin{abstract}
Serat Centhini (Suluk Tambanglaras or Suluk Tambangraras-Amongraga) is one of the greatest literary works in New Javanese literature. Its construction began in 1742 Java (1814 AD) during Sunan Pakubuwana IV. The main reference is the Jatiswara book which was made in 1711 Java or 1783 AD during Sunan Pakubuwana III. This article tracks the arithmetic information contained in Serat Centhini, including cardinal numbers, ordinal numbers, Javanese calendar, and candrasengkala. The research was carried out by using the literature study method of Serat Centhini which is translated into Indonesian and transliterated in Latin script. The results showed that Serat Centhini recorded quite a lot of mathematical information which was used in the daily life of Javanese people. The results of this study can be used as teaching materials for ethnomathematics.
\end{abstract}

Keywords: Arithmatics, Serat Centhini

\section{Introduction}

Based on the Canggal Inscription (Sanjaya/Gunung Wukir), the Javanese people have used the base ten (decimal) number, the place value system for units, tens, and hundreds, and using ten digits/numbers $0,1, \ldots, 9$ since 732 . Application of this knowledge includes pronunciation of numbers (cardinal and ordinal), sengkala (candrasengkala and suryasengkala), modulo, and arithmetic operations.

Serat Centhini is prepared as a book that collects all Javanese knowledge since the time of the Hindu Mataram Kingdom. In each volume of Serat Centhini, there is never directly stated mathematical knowledge. Is that so? In connection with this question, this article is intended to report the results of tracing mathematical knowledge recorded in Serat Centhini.

\section{Methods}

The purpose of writing this article is to answer the question of whether there is any content of mathematical knowledge in Serat Centhini. To answer this question, the literature search method was used. The literature in question is Serat Centhini which has been translated into Indonesian and transliterated into Latin script, consisting of 12 volumes (Figure 1). The original Serat Centhini was written in Javanese with a Javanese script.

\section{Discussion}

\subsection{Serat Centhini Overview}

Serat Centhini (Suluk Tambanglaras or Suluk Tambangraras-Amongraga) is stated as a Javanese encyclopedia. Serat Centhini gathers all kinds of science (born and inner) as well as Javanese culture so that it does not become extinct and remains sustainable at all times. Serat Centhini is delivered in the form of songs (a total of 725 songs), and the writing is grouped according to the type of song (Sinom, Mijil, Gambuh, Pangkur, Maskumambang, Dhandhanggula, Pangkur, Asmarandana, Pucung, Kinanthi, Gambuh, Durma, Megatruh, Jurudemung, and Salisir). 


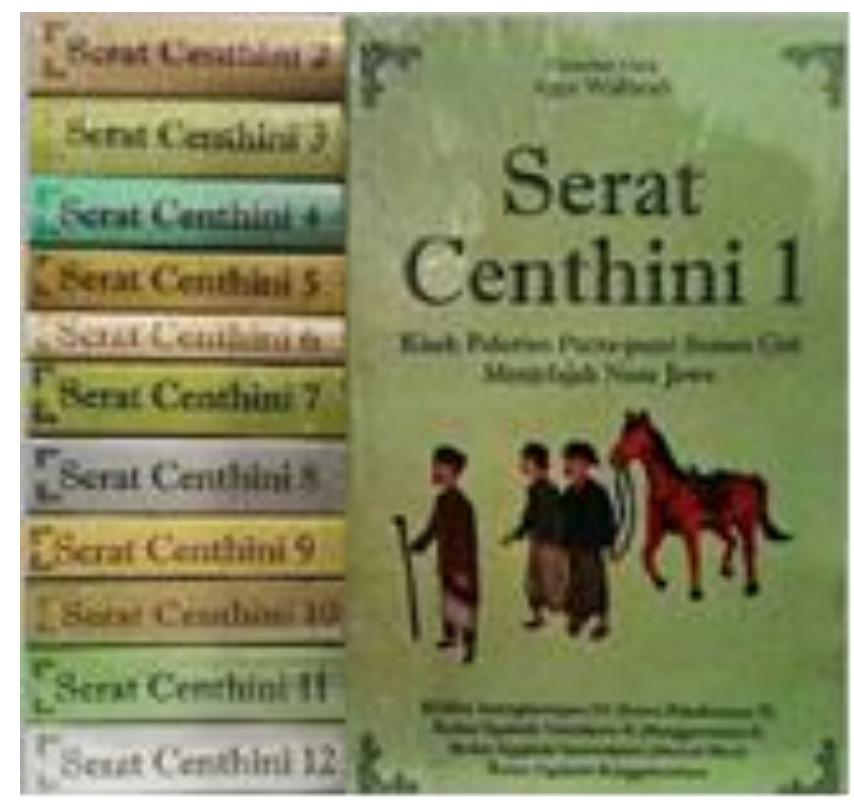

Figure 1: Serat Centhini (source: https://shopee.co.id/Serat-Centhini-Jilid-1-12)

As reflected in the early verses, this serat is written indeed with ambition as the baboning pangawikan Jawi (the main summary of Javanese knowledge). This serat covers various things in the mindset of the Javanese people, such as religious issues, mysticism, immunity, the world of keris, karawitan, dance, house building procedures, agriculture, primbon (horoscope), food and drink, customs, ancient stories about Java and others.

According to Sumahatmaka (1981), Serat Centhini was composed (written) at the request of Kanjeng Gusti Pangeran Adipati Anom in Surakarta, one of the sons of Kanjeng Susuhunan Pakubuwana IV, who later ascended the throne as Sunan Pakubuwana V. The preparation of Serat Centhini began Saturday Paing, 26 Sura 1742 Java. The year of writing Serat Centhini is marked by candrasengkala lamba Paksa Suci Sabda Ji states the year 1742 Java or 1814 AD. At that time, the one who reigned in the Surakarta Palace was Sunan Pakubuwana IV.

The main reference for the writing of Serat Centhini is the Book of Jatiswara written during the time of Sunan Pakubuwana III. The book of Jatiswara was written in 1711 Java $( \pm 1783$ AD) with the candrasengkala lamba marker 'Jati Tunggal Swara Raja'.

Serat Centhini was written by three poets from the Kasunanan Palace of Surakarta under the direct supervision of the crown prince Prince Adipati Anom who would later become Sunan Pakubuwana V. The three poets were

1. R. Ng. Ranggasutrasna,

2. R. Ng. Yasadipura II (formerly named R. Ng. Ranggawarsita I), and

3. R. Ng. Sastradipura.

The original Serat Centhini consists of 12 volumes with about 3500 pages, currently stored in Sanapustaka, Surakarta Palace. Serat Centhini descendants are stored in the Mangkunagaran Temple Library, Pahêman Radya Pustaka Sriwêdari, Sana Budaya Yogyakarta Museum and Gêdhong Gajah Jakarta Museum.

Before the composition, various references were collected by the three poets. R. Ng. Ranggasutrasna was in charge of exploring the eastern island of Java, R. Ng. Yasadipura II was in charge of exploring western Java, as well as R. $\mathrm{Ng}$. Sastradipura is in charge of performing the pilgrimage and perfecting his knowledge of Islam.

In his adventures, R. Ng. Ranggasutrasna returned first to the palace so that on the order of Prince Adipati Anom to immediately start writing. The candrasengkala lamba Paksa Suci Sabda Ji appears which can be interpreted as will (paksa) that is noble (suci) of the king (aji/ji) to the poets to write Javanese knowledge (sabda). When R. Ng. Ranggasutrasna completed volume 1, came R. Ng. Yasadipura II from West Java and R. Ng. Sastradipura from Mecca which later bore the name of K. H. Muhammad Ilhar. The work of each volume of Serat Centhini is done by experts. The section related to West Java was done by R. Ng. Sastradipura and related Islam was done by R. Ng. Sastradipura. However, in volume 1 written by R. Ng. Ranggasutrasna was also found wandering to the western part of Java (Parahiyangan/Sunda).

When Serat Centhini was completed up to volume 4, Prince Adipati Anom felt less assertive/accurate in conveying knowledge about sexual problems. Finally, Prince Adipati Anom completed volumes 5 to 10. The work of volumes 11 and 12 were handed back to the three poets.

The time setting of Serat Centhini was Mataram during the reign of Sultan Agung (1613-1645 AD). The main characters are three people who narrate the journey (adventure) of Sunan Giri's sons and daughters, namely Jayengresmi, Jayengraga/Jayengsari, and Ken Rancangkapti. At that time, Sunan Giri was conquered by Prince Pekik from Surabaya, on the orders of the Sultan Agung. Jayengresmi, accompanied by two students named Gathak and Gathuk, traveled/spiritual practice around the Majapahit palace to Blitar, Gamprang, Lodhaya forest, Tuban, 
Bojonegoro, Bagor forest, Gambirlaya, Mount Padham, Dhandher village, Kasanga, Sela, Gubug Merapi, Mount Prawata, Demak, Mount Muria, Pekalongan, Mount Panegaran, Mount Mandhalawangi, Tanah Pasundan, Bogor, the former palace of Pajajaran, Mount Salak, and then arrived in Karang (Prabowo, 2019).

On this journey, Jayengresmi experienced "spiritual maturity", as he met several teachers, magical figures in ancient Javanese mythology, and several locksmiths of sacred tombs in Java. In the meeting with the figures, he learned about all kinds of knowledge in the treasures of Javanese culture, from temples, the meaning of crows and prenjak sounds, the benefits of woodpeckers, instructions for making striped cloth, sexual intercourse time, calculation of dates, to stories Sheikh Siti Jenar. This experience and increase in wisdom made him later known as Seh (Sheikh) Amongraga. On the way, Sheikh Amongraga met with Ni Ken Tambangraras who became his wife, as well as his assistant Ni Centhini, who also participated in listening to his sermons.

Jayengsari and Rancangkapti, accompanied by a student named Buras, traveled to Sidacerma, Pasuruan, Ranu Grati, Banyubiru, the foot of Mount Tengger, Malang, Baung, Singhasari, Sanggariti, Tumpang, Kidhal, Pasrepan, Tasari, Mount Bromo, Ngadisari, Klakah, Kandhangan, Argopuro, Mount Raung, Banyuwangi, Pekalongan, Mount Perau, Dieng, to Sokayasa at the foot of Mount Bisma Banyumas.

On that trip, they both got knowledge about the customs of the land of Java, the Shari'a of the prophets, the story of Sri Sadana, knowledge of ablution, prayer, knowledge of the essence of Allah, His nature, and asthma (twenty characteristics), Hadith Markum, the calculation of slametan for the dead, as well as the Pandava and Kaurava officers.

After going through a journey that took years, finally, the three descendants of Sunan Giri were able to meet again and gather with their families and subordinates, even though it didn't last too long because Syekh Amongraga (Jayengresmi) then continued his spiritual journey to a higher level. , namely passed away from the face of the earth.

Part of the Serat Centhini (volumes 5-9) was presented to the King of the Netherlands by Sunan Pakubuwana VII (reigned 1757-1786 AD) as a pisungsung (gift). Until now, it is still stored in the Leiden University Library in the Netherlands. R. Ng. Ranggawarsita III added a new preface (which is a summary of volumes 1-4) to the pisungsung manuscript. The title of the serat is no longer Suluk Tambanglaras, but has been changed to Serat Centhini. The writing of Serat Centhini 'pisungsung' is marked by candrasengkala lamba 'Tata Resi Amulang Jalma' which states the year 1775 Javanese, consisting of 280 songs.

The Serat Centhini 'pisungsung' which was presented to the King of the Netherlands in 1912 AD was published in Latin script by Bataviaach Genootschap van Kunsten en Wetenschappen, an imprint of the Ruygrok \& Co Firm in Batavia. The book consists of 4 books, volumes 1 to 8 .

Balai Pustaka PN Publisher in 1931 also published a summary of Serat Centhini, which was made by R.M.A. Sumahatmaka, based on a manuscript belonging to the Mangkunegaran Palace Reksapustaka. The summary has been freely transcribed and translated in the form of a story, which is expected by the author to be easily understood by the wider community.

\subsection{Contents of Serat Centhini Arithmetic}

Serat Centhini contain various information related to arithmetic, including the pronunciation of numbers, the application of numbers in the form of numerology and pentungan, the use of cycles to express the year, mathematical calendars, and so on. The following are arithmetic-related themes contained in Serat Centhini.

Table 1: Contents of Serat Centhini Arithmetic

\begin{tabular}{|c|c|}
\hline Volumes & Arithmetic content \\
\hline 1 & $\begin{array}{l}\text { Javanese calendar; calculation of good and bad days; salvation for the dead; the size of the part of the house; } \\
\text { candrasangkala (Wahyudi, 2015a). }\end{array}$ \\
\hline 2 & $\begin{array}{l}\text { The origin of language and letters when building the Biblical tower; marriage and husband-wife relationship; luk } \\
\text { keris and luk spear (Wahyudi, 2015b). }\end{array}$ \\
\hline 3 & $\begin{array}{l}\text { Calculation of good days for several purposes; temples; Javanese calendar; calculation of the pros and cons of } \\
\text { matchmaking; playing card; rescue people from 3-1000 days; the characteristics of women are seen from the day of } \\
\text { birth on the Javanese calendar (Wahyudi, 2015c). }\end{array}$ \\
\hline 4 & $\begin{array}{l}\text { Jayabaya forecast; three efficacious stones; Serat Waduaji which contains the names of punggawa (employees) and } \\
\text { royal soldiers; the level of students in Buddhism, namely Upasaka, Sangha, and Samana (Wahyudi, 2015d). }\end{array}$ \\
\hline 6 & The Javanese calendar follows the lunar calendar; wuku; weekly; season calendar (pranatamangsa) (Wahyudi, 2015e). \\
\hline 7 & Wuku; good days and bad days (Wahyudi, 2015f). \\
\hline 8 & $\begin{array}{l}\text { Pawukon; pranatamangsa; adewan; padangon; pancasuda; stinging descent; Taliwangke; samparwangke; paringkelan; } \\
\text { and Javanese horoscope (Wahyudi, 2015g). }\end{array}$ \\
\hline 12 & Candra sometimes; keratabasa; the meaning of Javanese letters; dasanama (Wahyudi, 2015h). \\
\hline
\end{tabular}




\subsection{Javanese calendar}

The use of the Javanese calendar is found in the early part of volume I which explains when the writing of the Serat Suluk Tambangraras (Serat Centhini) was started, namely nêmlikur sabtu paing | lèk mukaram wêwarsèku| mrakèh hyang surènggana $\mid$ bathara yama dewa ri $\mid$ amawulu wogan suajag sumêngka $\mid$ pancasudaning satriya $\mid$ wibawa lakuning gêni $\mid$ windu adi mangsa sapta $\mid$ sangkala angkaning warsi $\mid$ paksa suci sabda ji $\mid$.

The elements in the Javanese calendar system used in Serat Centhini are tithi (date), period (month), the cycle of five, six, seven, eight, and nine days, wuku, windu, pranatamangsa, and pancasuda.

Table 2: The elements in the Javanese calendar system

\begin{tabular}{|c|c|c|}
\hline No & Elements & 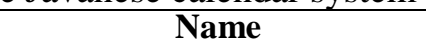 \\
\hline 1 & Tithi & Nemlikur \\
\hline 2 & Masa & Mukaram \\
\hline 3 & Pancawara (pasaran) & Paing \\
\hline 4 & Sadwara (paringkelan) & Mawulu \\
\hline 5 & Saptawara (padinan) & Sabtu \\
\hline 6 & Asthawara (padewan) & Yama \\
\hline 7 & Sangawara (padangon) & Wogan \\
\hline 8 & $W u k u$ & Marakeh \\
\hline 9 & Windu & Adi \\
\hline 10 & Pranatamangsa & Sapta \\
\hline 11 & Pancasuda & Satriya wibawa lakuning gêni \\
\hline 12 & Tahun & paksa suci sabda ji \\
\hline
\end{tabular}

These elements are different from the calendar elements used in the Majapahit era.

Table 3: The elements in the Javanese calendar system in the Majapahit era

\begin{tabular}{clcc}
\hline No & \multicolumn{1}{c}{ Elements } & Majapahit & Mataram Islam \\
\hline 1 & Tithi & Yes & Yes \\
2 & Masa & Yes & Yes \\
3 & Pancawara (pasaran) & Yes & Yes \\
4 & Sadwara (paringkelan) & Yes & Yes \\
5 & Saptawara (padinan) & Yes & Yes \\
6 & Asthawara (padewan) & No & Yes \\
7 & Sangawara (padangon) & No & Yes \\
8 & Wuku & Yes & Yes \\
9 & Windu & No & Yes \\
10 & Pranatamangsa & No & Yes \\
11 & Pancasuda & No & Yes \\
12 & Tahun & Yes & Yes \\
13 & Grahacara & Yes & No \\
14 & Naksatra & Yes & No \\
15 & Dewata & Yes & No \\
16 & Mandala & Yes & No \\
17 & Yoga & Yes & No \\
18 & Muhurta & Yes & No \\
19 & Parwesa & Yes & No \\
20 & Karana & Yes & No \\
21 & Rasi & yes & No \\
\hline & & &
\end{tabular}

\subsection{Sengkala Lamba}

The number of years which marks the beginning of the writing of Serat Centhini is not stated in numerical form but in the form of candrasengkala lamba which reads paksa suci sabda ji. 


\subsection{Number of Cardinals and Ordinals in Serat Centhini}

Cardinal numbers are used to express the amount of something. Serat Centhini are made in the form of song lyrics so that everything is in the form of words. There are no number symbols found on Serat Centhini.

Serat Centhini is written in the New Javanese language which is currently still in use. In the New Javanese language, Krama Inggil and Ngoko are found. Kromo Inggil is used with older people or people who are respected. Ngoko language is used in the equal interlocutor. As a result, number pronunciations for Kromo Inggil and Ngoko are found. Pronunciations for numbers in Kawi (Old Javanese) are also still used in Serat Centhini.

Serat Centhini which consists of 12 volumes and Serat Centhini 'pisungsung' are both written in New Javanese script so that the pages of the book find the use of New Javanese numerals. The use of New Javanese numerals is also found in the numbering of tembang verses.

Number pronunciations found on Serat Centhini can be divided into two types, namely cardinal and ordinal numbers. Cardinal numbers are used to express the amount of something. An ordinal number is used to express a sequence. Table 2 presents the pronunciations of cardinal and ordinal numbers found in Serat Centhini.

Table 3: The elements in the Javanese calendar system in the Majapahit era

\begin{tabular}{|c|c|c|c|c|c|c|c|}
\hline \multicolumn{4}{|c|}{ Pronunciation of Cardinal Numbers } & \multicolumn{4}{|c|}{ Pronunciation of Ordinal Numbers } \\
\hline \multirow[b]{2}{*}{ English } & \multirow{2}{*}{$\begin{array}{l}\text { Old Javanese } \\
\quad \text { (Kawi) }\end{array}$} & \multicolumn{2}{|c|}{ New Javanese } & \multirow[b]{2}{*}{ English } & \multirow{2}{*}{$\begin{array}{l}\text { Old Javanese } \\
\text { (Kawi) }\end{array}$} & \multicolumn{2}{|c|}{$\begin{array}{r}\text { New Javanese } \\
\end{array}$} \\
\hline & & Ngoko & $\begin{array}{c}\text { Krama } \\
\text { Inggil }\end{array}$ & & & Ngoko & Krama Inggil \\
\hline Zero & Das & Nol & $\mathrm{Nol}$ & - & - & - & - \\
\hline One & $E k a$ & Siji & satunggal & First & $\begin{array}{l}\text { Kaping } \\
\text { sapisan }\end{array}$ & $\begin{array}{l}\text { Dhingin, sapisan, pisan, } \\
\text { ping pisan, kaping } \\
\text { sapisan }\end{array}$ & sapindhah \\
\hline Two & Dwi & Loro & Kalih & Second & Ping $d w i$ & Pindho & Kaping kalih \\
\hline Three & Tri & Telu & Tigo & Third & Kaping tri & Ping telu & Kaping tigo \\
\hline Four & Catur & Papat & Sekawan & Fourth & Kaping catur & Ping pat & $\begin{array}{l}\text { Kaping } \\
\text { Sekawan }\end{array}$ \\
\hline Five & Panca & Lima & Gangsal & Fifth & Kaping panca & Ping lima & Kaping gangsal \\
\hline Six & Sad & $\begin{array}{l}\text { Nem, } \\
\text { Nenem }\end{array}$ & $\mathrm{Nem}$ & Sixth & Kaping sad & Ping nem & Kaping Nem \\
\hline Seven & Sapta & $\begin{array}{l}\text { Pitu, } \\
\text { pipitu }\end{array}$ & Pitu & Seventh & Kaping sapta & Ping pitu & Kaping Pitu \\
\hline Eight & Asta & Wolu & Wolu & Eighth & Kaping asta & Ping wolu & Kaping Wolu \\
\hline Nine & Nawa & Sanga & Sanga & Ninth & Kaping nawa & Ping sanga & Kaping Sanga \\
\hline Ten & Dasa & Sepuluh & Sedasa & Tenth & Kaping dasa & Ping sapuluh & Kaping Sedasa \\
\hline Eleven & Ekadasa & Sewelas & $\begin{array}{l}\text { Setunggal } \\
\text { welas }\end{array}$ & Eleventh & $\begin{array}{l}\text { Kaping } \\
\text { ekadasa }\end{array}$ & Ping sewelas & $\begin{array}{l}\text { Kaping } \\
\text { Setunggal } \\
\text { welas }\end{array}$ \\
\hline Twelve & Dwadasa & Rolas & Kalih welas & Twelfth & $\begin{array}{l}\text { Kaping } \\
\text { dwadasa }\end{array}$ & Ping rolas & $\begin{array}{l}\text { Kaping Kalih } \\
\text { welas }\end{array}$ \\
\hline
\end{tabular}

In the pronunciation of an ordinal number, the word 'kaping' can be replaced with 'ping'. The meaning of kaping lima and ping lima are the same. The change from kaping to ping or vice versa is related to the number of syllables that must be met in each song array. Such changes are not always related to the number of syllables. Likewise, the change from sapisan to pisan. The term 'ping' is also used for the synonym "times" in a multiplication operation.

The pronunciation of cardinal numbers is sometimes used to pronounce ordinal numbers. So, the pronunciation of telu can mean the number of three (cardinal) or third (ordinal). This applies to both Old Javanese, New Javanese Ngoko and New Javanese Kromo. The opposite is not true. The use of cardinal numbers as ordinal numbers is highly dependent on the meaning per sentence and the meaning of the series of sentences.

Some words do not directly indicate the order such as rumiyin or kawitan (first), pungkasan (last), kapindho (second). The pungkasan do not always clearly state the latter in what order. The sequence always starts with the first. In contrast to the number of things that can be expressed as zero.

\section{Conclussion}

Serat Centhini collected Javanese knowledge from the time of the Hindu Mataram Kingdom. This knowledge is the knowledge that has been used in everyday life. One of them is about arithmetic knowledge.

Serat Centhini records the use of arithmetic which is applied in the daily life of Javanese people. From the search results, it is known that the cardinal, ordinal, Javanese calendar, and lamba sengkala numbers are known. The results of this study can be used as teaching materials for ethnomathematics. 


\section{References}

Prabowo, A., Tripena, A., Sugandha, A., \& Riyadi, S. (2019). On the Javanese Ethnoastronomy: Time Dimension on the Calendrical Inscription on Majapahit Era until Now. Journal of Physics Conf. Ser., 1179, 012159.

Sumahatmaka, R.M.A. (1981). Ringkasan Centini (Suluk Tambanglaras). Jakarta: PN Balai Pustaka.

Wahyudi, A. (2015a). Serat Centhini 1: Kisah Pelarian Putra-Putri Sunan Giri Menjelajahi Nusa Jawa. Yogyakarta: Penerbit Cakrawala.

Wahyudi, A. (2015b). Serat Centhini 2: Pengembaraan Cebolang Mencari Jati Diri. Yogyakarta: Penerbit Cakrawala.

Wahyudi, A. (2015c). Serat Centhini 3: Perjalanan Cebolang Meraih Ilmu Makrifat. Yogyakarta: Penerbit Cakrawala.

Wahyudi, A. (2015d). Serat Centhini 4: Antara Cebolang dan Nyai Demang. Yogyakarta: Penerbit Cakrawala.

Wahyudi, A. (2015e). Serat Centhini 6: Pernikahan Syekh Amongraga dan Tambangraras. Yogyakarta: Penerbit Cakrawala.

Wahyudi, A. (2015f). Serat Centhini 7: Wejangan Syekh Amongraga tentang Ilmu Kesejatian. Yogyakarta: Penerbit Cakrawala.

Wahyudi, A. (2015g). Serat Centhini 8: Ujung Pengembaraan Jasmani Syekh Amongraga. Yogyakarta: Penerbit Cakrawala.

Wahyudi, A. (2015h). Serat Centhini 12: Dua Sejoli Hidup Bahagia di Alam Kesempurnaan. Yogyakarta: Penerbit Cakrawala. 